\title{
Pendidikan di Indonesia Menyongsong Era Disrupsi 4.0
}

\author{
M. Ridwan ${ }^{1 *}$ \\ ${ }^{1}$ Kementerian Agama Provinsi Bangka Belitung, Indonesia
}

\begin{abstract}
Abstrak: Keluasan dan kedalaman wawasan akan memberikan warna dan makna tersendiri, di dalam melakukan langkah-langkah pembangunan "capacity building" pendidikan dan memposisikannya menjadi urgen. Misalnya seperti dalam konteks mengangkat kompetensi guru. Kemiskinan wawasan melihat perubahan paradigma pendidikan, memperkuat dugaan bahwa itu merupakan salah satu faktor penyebab yang mengakibatkan melorotnya mutu pendidikan Indonesia karena pelaku pendidikan tidak mampu membawa pendidikan itu ke arah yang tepat yaitu sesuai dengan perkembangan dan tuntutan zaman. Wawasan paradigma pendidikan ini menjadi sesuatu yang urgen untuk dipahami oleh para pendidik sebab dapat memberikan pemikiran hingga mempengaruhi di dalam menjalankan tugas dan fungsinya. Inovatif pemahaman tentang perubahan paradigma pendidikan dan untuk dapat menentukan paradigma pendidikan yang lainnya sejalan dengan kemajuan ilmu pengetahuan, sebab paradigma itu muncul karena akibat kemajuan ilmu pengetahuan, baik lantaran murni atau aplikasi. Paradigma pendidikan Indonesia pertama-tama di tanah air adalah paradigma sekolah rakyat, bergeser ke paradigma sekolah negara, bergeser ke paradigma sekolah masyarakat.
\end{abstract}

Kata Kunci: paradigma, pendidikan, disrupsi 4.0

\begin{abstract}
The breadth and depth of insight will give its own color and meaning, in carrying out the steps for developing educational "capacity building" and positioning it to be urgent. For example, in the context of raising teacher competence. The poverty of insight seeing the change in the educational paradigm, reinforces the notion that it is one of the factors causing the decline in the quality of Indonesian education because education actors are unable to bring education in the right direction, namely in accordance with the developments and demands of the times. This educational paradigm insight is something that is urgent for educators to understand because it can provide thoughts to influence in carrying out their duties and functions. Innovative understanding of changes in educational paradigms and to be able to determine other educational paradigms in line with the progress of science, because the paradigm arises because of the progress of science, either because of pure or application. The paradigm of Indonesian education, first of all, in the country is the community school paradigm, shifting to the state school paradigm, shifting to the community school paradigm.
\end{abstract}

Keywords: paradigm, education, disruption 4.0

\section{Pendahuluan}

Sistem pendidikan yang selama ini dikelola dalam suatu keadaan sesuatu pada area tertentu tidak mudah berubah kecuali dalam waktu yang relatif lama dalam suasana birokratik dan sentralistik dianggap sebagai salah satu penyebab terpuruknya kualitas pendidikan nasional. Sistem

\footnotetext{
* Corresponding Author: M. Ridwan (rahmatbarid30@gmail.com). Kementerian Agama Provinsi Bangka Belitung, Indonesia
} 
birokratis selalu menempatkan kekuasaan sebagai faktor yang paling menentukan dalam proses pengambilan keputusan.

Sekolah-sekolah terkungkung oleh kekuasaan birokrasi yang menggurita sejak tingkat pusat hingga tingkat daerah bahkan terkesan semakin buruk dalam era desentralisasi ini, artinya menurut M. Sirozi (2003), menyatakan desentralisasi artinya kewenangan sementara masa transisi 5-10 tahun sambil menunggu kesiapan Kabupaten dan Kota untuk membiayai, membuat kurikulum, memfasilitasi keberadaan SMU/MA, Museum Negeri, dan lain-lain. Kepala sekolah dan guru sebagai pihak yang paling memahami realitas pendidikan berada pada tingkat yang dikendalikan. Padahal, merekalah yang seharusnya paling berperan sebagai pengambil keputusan dalam mengatasi berbagai persoalan yang menghadang upaya peningkatan mutu pendidikan.

Bagaimana hasil dari sistem pendidikan birokratis dan sentralistik itu? Berbagai laporan baik ditingkat internasional maupun regional menunjukkan bahwa kualitas pendidikan Indonesia selalu menempati posisi nomor sepatu. Dalam laporan survei UNDP tahun 1991, Iluman Deplovement Index (HDI) Indonesia menempati peringkat ke 76 dari 230 negara, tahun 1997 peringkat ke 96 dari 174 Negara, tahun 2000 peringkat ke 102, tahun 2002 peringkat ke 109 dari 174 negara, 2003 peringkat ke 112 dari 174 negara. Studi kemampuan tingkat Sekolah Dasar (SD) yang dilaksanakan oleh IEA tahun 2000 melaporkan bahwa siswa SD Indonesia berada pada urutan ke 38 dari 39 negara. Sementara itu kemampuan matematika siswa Sekolah Lanjutan Tingkat Pertama (SLTP) Indonesia berada pada posisi ke 39 dari 42 negara. Untuk kemampuan Ilmu Pengetahuan Alam (IPA), siswa SLTP Indonesia menempati urutan ke 40 dari 42 negara peserta. The Third International Mathematics and Science
Compared to Other Countries (2002). Melaporkan bahwa prestasi siswa Indonesia dalam bidang studi matematika hanya menempati peringkat ke 39 dari 42 negara peserta yang diteliti. Sedang di bidang Sains (Fisika, Biologi, Kimia dan Geografi), siswa Indonesia menempati peringkat ke 40 dari 42 negara (Seminar Nasional, 2005).

\section{Paradigma Pendidikan Nasional}

Sebagaimana pendapat Thomas Khun (1976), menguraikan bahwa suatu paradigma (perubahan pemikiran, pola ke arah yang lebih baik) ilmu pengetahuan diawali oleh aktifitas yang terpisah-pisah. Aktifitas-aktifitas itu disusun sedemikian rupa sehingga menjadi suatu paradigma tunnggal. Paradigma itu kemudian pada perkembangannya tidak lagi sesuai dengan perkembangan ilmu, maka ia akan mengalami falsifikasi (bergeser tertinggal oleh kemajuan ilmu pengetahuan) sehingga berada pada keadaan krisis. Ketika paradigma itu tidak mampu mengatasi krisis yang berkembang, maka terjadilah anomali (suatu aliran air yang semestinya tidak perlu terjadi, karena tidak bermakna lagi) yang berpuncak pada revolusi. Revolusi ini melahirkan paradigma yang baru.

Dengan memakai pemikiran Khun dalam melihat perkembangan paradigma pendidikan nasional, dapat disebut paradigma pendidikan pertama di tanah air adalah sekolah rakyat. Paradigma ini lahir sejak berdirinya Boedi Oetomo pada 20 Mei 1908 yang dimotori oleh dr. Soetomo, dr. Wahidin Soedirokoesudo, dkk. Pada masa itu, ideologi pendidikan diarahkan pada pengobaran semangat kebangsaan. Sekolah rakyat ini diartikan oleh rakyat secara Swadaya. Substansinya adalah merupakan sebuah institusi sosial. Walaupun sangat sederhana dan berhadapan dengan tekanan dan propaganda kolonial pendidikan saat itu membuahkan hasil yang signifikan dan mengantarkan Indonesia mencapai kemerdekaan. 
Setelah kemerdekaan, dengan berbagai modifikasi, sekolah rakyat menjadi paradigma pendidikan nasional sampai pada masa Orde Baru. Pada awal pemerintah Orde Baru, paradigma pendidikan ini telah mengalami krisis. Target pemerintah mengejar pertumbuhan ekonomi dan peningkatan kualitas pendidikan untuk memenuhi amanah pembukaan UUD 1945, yaitu mencerdaskan kehidupan bangsa ternyata tidak dapat didukung oleh sistem pendidikan yang ada. Paradigma sekolah rakyat dianggap terlalu tradisional dan lamban bahkan sulit untuk mengangkat kualitas pendidikan nasional sebagai salah satu indikator pertumbuhan ekonomi. Sekolah rakyat juga tidak dapat melahirkan pemerataan perolehan pendidikan bagi seluruh warga negara. Anomali paradigma sekolah rakyat ini kemudian melahirkan revolusi pendidikan yang mencapai puncaknya pada tahun 1973. Dengan keluarnya Instruksi Presiden (Inpres) SDN No. 10 tahun 1973, paradigma sekolah rakyat digantikan oleh paradigma sekolah negara.

Paradigma sekolah negara berpandangan bahwa sekolah harus dikelola sepenuhnya oleh negara agar terjadi pemerataan pendidikan bagi seluruh warga negara. Didirikannya sekolahsekolah Inpres yang diikuti oleh sentralitas kebijakan pendidikan, merupakan langkah awal penggerogotan akses rakyat dalam pengelolaan pendidikan. Sekolah sebagai institusi budaya berubah menjadi institusi negara. Seluruh kebijakan pendidikan formal (bahkan juga pendidikan informal dan nonformal) diatur oleh pemerintah pusat. Sekolah sebagai pelaksana teknis yang paling akhir hanya menerima petunjuk yang telah dibakukan secara nasional.

Perguruan tinggi juga tidak luput dari overregulasi yang dilakukan oleh pemerintah pusat. Kebebasan mimbar akademik kemudian dianggap sebagai ancaman kekuasaan pemerintah.
Pelaksanaan penataran Pedoman Penghayatan Pengamalan Pancasil (P4) bagi mahasiswa baru merupakan salah satu contoh kongkrit dari pelembagaan ideologi kekuasaan dalam perguruan tinggi. Fakta lain yang sulit hilang dari ingatan kita adalah banyaknya aktivitas kampus yang dijebloskan ke dalam penjara tanpa atau dengan proses hukum. Bahkan, banyak di antara anak bangsa itu tewas di ujung timah panas atau hilang tanpa jejak ketika mencoba menyatakan keadilan.

Dalam perjalanannya selama tiga dasawarsa, paradigma sekolah negara ternyata juga melahirkan anomali-anomali antara lain melahirkan tirani, eksplorasi, ketidakadilanm ketidakberdayaan masyarakat, kemerosotan akhlak, penghilangan budaya-budaya lokal, keterpurukan kualitas pendidikan, dan berbagai masalah sosial lainnya. Ivan Illich mengatakan bahwa keadaan sistem seperti ini justru melakukan anti-edukasi. Sedangkan Paulo Fraire mengemukakan istilah pendidikan yang membelenggu atau menindas.

Pada dekade pertengahan 1990-an paradigma sekolah negara mendapat sorotan tajam dari berbagai kalangan, baik dalam negeri atau masyarakat internasional yang menjadikan paradigma ini mengalami puncak krisisnya pada tahun 1997, yakni jatuhnya rezim otoriter Orde Baru. Seiring dengan ini, paradigma sistem sekolah negara berupa ke sistem pendidikan sekolah masyarakat yang dipaket dalam program manajemen Berbasis Sekolah (MBS).

\section{Hakekat Paradigma Baru Pendidikan Nasional}

Menurut Hidayat (2000), setidaknya ada tiga alasan utama diterapkannya otonomi daerah, yaitu (1) political equality, guna meningkatkan partisipasi politik masyarakat daerah dalam rangka meningkatkan demokratisasi dalam mengelola negara, (2) Local accountability, guna 
meningkatkan kemampuan dan tanggung jawab pemerintah daerah dalam mewujudkan hak dan aspirasi masyarakat di daerah, (3) Local Responsiveness, yaitu meningkatkan respon pemerintah daerah terhadap masalah-masalah social ekonomi yang terjadi di daerahnya.

Seiring dengan otonomi daerah, pemerintah melakukan reorientasi penyelenggaraan pendidikan, dari sentralisasi kepada desentralisasi pendidikan. Dengan paradigma baru ini, diharapkan pemerintah pusat tidak lagi melakukan higimoni terhadap kebijakan pendidikan, tetapi lebih diserahkan kepada kepala sekolah, yang mengetahui proses kondisi di lapangan/sekolah, sudah siapkah kader kepala sekolah untuk mampu mengimplementasikan hal itu. Salah satu langkah yang telah ditempuh ke arah desentralisasi pendidikan itu adalah digesernya paradigma manajemen berbasis pusat kepada Manajemen Berbasis Sekolah (MBS). MBS merupakan model manajemen yang memberikan otonomi, fleksibelitas kepada sekolah, dan mendorong partisipasi secara langsung warga sekolah dan masyarakat untuk mengelola pendidikan dalam rangka peningkatan mutu pendidikan.

Masyarakat sebagai stakeholder pendidikan berkepentingan akan keberhasilan pendidikan, karena mereka dalah pembayar pendidikan baik secara langsung ataupun tidak langsung seperti melalui pajak. Sehingga sekolah-sekolah seharusnya bertanggung jawab pada masyarakatnya. Entitas stakeholder yang sangat kompleks dan tak terbatas itu kemudian disederhanakan agar memudahkan sekolah berinteraksi dengannya. Penyederhanaan itu dimaksudkan sebagai perwakilan stakeholder. Untuk maksud itu, Program Pendidikan Nasional (Propenas) tahun 2000-2004 mengamanatkan pembentukan Dewan Pendidikan di tingkat kabupaten/kota dan komite Sekolah pada setiap atau beberapa satuan sekolah, dalam rangka pemberdayaan dan peningkatan peran serta masyarakat dalam pendidikan, tetapi akhir ini dalam konteks pendidikan gratis maka konsep tersebut terlihat mengalami reduksi makna dan pembiasan. Walaupun konsep komite sekolah itu ditindak lanjuti dengan adanya suatu Keputusan Menteri Pendidikan Nasional nomor 044/2002 tentang Dewan Pendidikan dan Komite Sekolah, telah berjalan dalam kurun waktu empat tahun telah berjalan. Dengan demikian, secara idealitas Komite Sekolah adalah pendorong terealisasi MBS di setiap satuan pendidikan, kendatipun secara kelembagaan MBS belum dapat dievaluasi secara efektivitasnya, sebab terkadang disinyalir adanya lembaga itu menjadikan beban baru yang merupakan pekerjaan rumah harus bagi sekolah-sekolah.

Dalam konteks era pendidikan sekolah masyarakat sebagai buah reformasi yang lalu dibidang pendidikan pada satu sisi patut disyukuri, tetapi pada sisi lainnya tampak kasat mata masih tetap harus diperjuangkan secara terus menerus dan konsisten dengan komitmen dan moralitas tinnggi, hingga perubahan-perubahan yang terjadi tetap dipimpin perubahannya, bukan perubahanperubahan yang terjadi memimpin perubahannya. Oleh karena itu untuk dapat memimpin perubahanperubahan yang terjadi, harus dapat memahami situasi dan kondisi zamannya dengan berbagai perubahan yang terjadi didalamnya dan pergeseran berbagai paradigma pendidikan dari yang lama ke paradigma pendidikan baru.

Beberapa catatan penting dalam memahami paradigma pendidikan baru ini dibandingkan dengan paradigma sebelumnya ada 15 paradigma pendidikan baru yang dijelaskan dalam uraian berikut ini: 
1. Dari subordinasi menuju otonomi

Manajemen yang serba sentralistis menjadikan sekolah sebagai sub-ordinasi dari pemerintah/ pendidikan tingkat pusat. Proses pendidikan yang dijalankan dengan undermanaged dengan pendekatan sarwanegara (state-driven) telah menempatkan sekolah pada posisi yang marginal tidak berdaya, tidak memiliki keberanian moral (prakarsa) untuk berinisiatif melakukan inovasi-inovasi penyelenggaraan pendidikan di sekolah. Sekolah juga menjadi tidak mandiri, terjadi penyumbatan dan bahkan pemasungan demokrasi. Sekolah tidak peka dan jeli dalam menangkap permasalahan, kebutuhan, dan aspirasi pendidikan dari masyarakat sebagai stakeholder.

Pada pendekatan baru dengan konsep MBS sekolah diberikan suatu peluang dengan konsep otonom pendidikan pada tingkat sekolah untuk berbuat yang terbaik bagi sekolah. Sekolah harus bersifat professional dengan suatu kemauan dan keyakinan bahwa perubahan pendidikan tidak akan terjadi jika sekolahnya sendiri tidak berubah. Jadi, otonom sekolah adalah kewenangan sekolah untuk mengatur dan mengurua kepentingan sekolah menurut prakarsanya sendiri berdasarkan aspirasi warga sekolah sesuai dengan koridor-koridor pada berbagai peraturan dan perundang-undangan pendidikan nasional yang berlaku.

2. Dari pengambilan keputusan terpusat ke pengambilan keputusan partisipasi

Keputusan yang diambil secara sentralistik cenderung menyeragamkan kebijakan untuk semua sekolah, pada hal situasi dan kondisi masingmasing sekolah itu berbeda satu dengan yang lainnya. Dengan pendekatan konsep MBS dan implementasinya dimana keterlibatan setiap warga sekolah dalam pengambilan keputusan di tingkat sekolah, sehingga menghasilkan keputusan yang partisipatif. Essensi proses pengambilan keputusan partisipatif adalah untuk mencari wilayah kesamaan antara kelompok-kelompok kepentingan yang terkait dengan sekolah Stakeholder, yaitu kepala sekolah, guru, siswa, orangtua siswa dan pemerintah atau yayasan.

Pengambilan keputusan partisipatif adalah suatu cara mengambil keputusan melalui penciptaan lingkungan yang terbuka dan demokratis, dimana setiap warga sekolah misalnya guru, siswa, pegawai, dan orangtua siswa dan masyarakat sekitarnya, didorong untuk terlibat secara langsung dalam proses pengambilan keputusan, untuk memberikan kontribusi untuk mewujudkan visi dan misi serta tujuan sekolah yang sudah barang tentu untuk mencapai tujuan pendidikan nasional, sebab tujuan pendidikan nasional itu tercapai bila sekolah-sekolah telah dapat pula mencapai tujuannya.

3. Dari ruang gerak kaku menuju ruang gerak luwes

Pendidikan yang dikelola secara sentralistik telah menjadikan ruang gerak sekolah menjadi kaku. Kekakuan itu dapat dilihat dari orientasinya yang sangat normatif karena terlalu banyak lapislapis birokrasi. Birokrasi mengendalikan fungsi, bukan fungsi yang mengendalikan birokrasi, Uniformitas telah memasuk kreativitas, dan tradisi secara seremonial yang penuh kepalsuan sudah menjadi kebiasaan.

Pada pendekatan MBS ruang sekolah sangat luwes karena sebagian besar pengambilan kebijakan diserahklan kepada sekolah. Hal ini memberikan keleluasaan kepada sekolah untuk mengelola seluruh potensi yang ada di sekolahnya dengan konteks sosial, geografis, dan teknologi lokal dan ekonomi untuk mencapai tujuan pendidikan nasional yang memanusiakan manusia. 
4. Dari pendekatan birokrasi menuju pendekatan profesionalisme

Pola sentralistik menjadikan eksistensi birokrasi lebih dominan dari pada tanggung jawab professional, sehingga kreativitas sekolah pada umumnya dan guru pada khususnya terpasung dan terbunuh. Misalnya seperti pada proses belajar mengajar yang diselenggarakan guru di kelas atau di sekolah tidak lebih mementingkan jawaban soal secara baku yang dianggap benar oleh guru, karena siswa tidak terbiasa dengan mengembangkan dan membandingkan dengan daya kreasi, nalar, dan eksperimentasi peserta didik untuk menemukan kemungkinan-kemungkinan baru. Tidak ada toleransi terhadap kekeliruan akibat kreativitas berpikir, karena yang benar adalah apa yang dipresentasikan oleh guru, padahal, proses belajar mengajar atau pembelajaran yang semestinya lebih memungkinkan proses pencarian jawaban dibandingkan memiliki jawaban.

Paradigma pendidikan baru adalah berupaya membalikkan sistem itu ke arah yang sebaliknya dengan pendekatan MBS. Menurut Mastuhu, yang menyatakan pendidikan visioner terjadi perubahan ke depan dari paradigma SDM professionalisme menuju ke paradigma personal humility. SDM personal humility, yaitu SDM yang tidak professional dibidangnya tetapi ia adalah SDM yang memiliki nilai-nilai abadi, keimanan dan ketakwaan, sedangkan SDM professional tidak memiliki nilai tersebut pada dirinya (Mastuhu, 2005).

5. Dari manajemen sentralistik menuju manajemen desentralistik

Pendidikan yang diatur secara sentralistik telah menimbulkan fenomena-fenomena yang disfungsional dimana sekolah menjadi tidak berdaya untuk melaksanakan fungsinya yang sesungguhnya, tetapi di dalam manajemen desentralistik diharapkan lebih memiliki kecenderungan memberikan keluwesan kewenangan kepada sekolah untuk mengelola sekolah. Dengan pendekatan desentralistik ini, dimungkinkan bahwa sekolah lebih dapat berdaya di semua sisi diantaranya sekolah dapat mengambil keputusan-keputusan yan dibuat dan diambil diharapkan menjadi efektif dan efisien. Dalam hal ini, Ivan Illich menulis bahwa lembaga-lembaga pendidikan yang sentralistik malah menghancurkan tujuan-tujuan yang ingin dicapai oleh lembaga. Dalam konteks ini, hancurnya tujuan sekolah yang hendak dicapai justru bisa berakibat menghancurkan pendidikan umumnya, sebab sekolahlah sebagai ujung tombak pelaksanaan pendidikan itu, nah kalau sekolah hancur tujuannya jelas berakibat pula pada hancurnya pendidikan.

Menurut Murwani (1999), kewenangan pemberdayaan daerah otonomi, kewenangan tersebut harus mengacu pada tiga kriteria, (1) kriteria identitas serta integritas bangsa dan negara, bahwa pengelolaan urusan pemerintah bidang pendidikan harus diarahkan pada upaya mempertahankan dan memelihara identitas dan integritas bangsa dan negara, baik secara internal maupun eksternal, (2) Kriteria pelayanan, bahwa aspek pelayanan pusat pada bidang pendidikan yang menjadi kewenangan pemerintah adalah yang menyangkut kepentingan nasional dan internasional berdasarkan keputusan politik, (3) Kriteria teknologi strategis, bahwa pengelolaan urusan pemerintah harus dapat memanfaatkan teknologi canggih dan memerlukan sumber pembiayaan yang tinggi, serta membutuhkan kualifikasi sumber daya manusia yang tinggi pula.

Menurut M. Sirozi (2004), paradigma dari sentralisasi ke desentralisasi membuka peluang baru bagi dunia pendidikan. Diantara peluang itu adalah kebebasan untuk melakukan inovasi dan mengembangkan program pendidikan yang relevan 
dengan nilai masyarakatnya. Desentralisasi akan menghilangkan sistem monopoli dan membuat suatu sistem lebih siap menerima inovasi (BenDavid, 1984). Sebaliknya, " Sistem desentralisasi lebih efektif dalam melahirkan dan menyeleksi jenis-jenis peran dan organisasi ketimbang sistem sentralisasi (decentralized have been types of roles and productions than centralized one) "(BenDavid, 1984).

6. Dari kebiasaan diatur menuju kebiasaan motivasi diri

Pola perilaku yang cenderung menunggu perintah dan kebiasaan diatur akan berubah menjadi pola perilaku baru yang bercirikan motivasi diri. Misalnya seperti pada pembuatan program pengajaran bukan mengacu pada program yang Bapak senang, tetapi berorientasi visi dan misi yang dibuat. Perubahan perilaku dari tidak ada rasa memiliki (Sence of Belonging) ke mempunyai rasa memiliki. Jika semua warga sekolah telah ada rasa memiliki, tidak cukup dengan rasa memiliki saja, tetapi pada gilirannya memerlukan rasa bertanggungjawab (Sence of Responsibility). Makin besar kedua rasa itu dapat meningkatkan partisipasi tiap warga sekolah dalam pengambilan keputusan, maka memungkinkan akan memberikan porsi lebih besar pada komponen sekolah untuk melakukan yang terbaik bagi sekolah, dan memungkinkan porsi lebih besar untuk memiliki tanggungjawabnya pada sekolah. Menurut E. Mulyasa (2004), keberhasilan lembaga pendidikan ditentukan oleh bayak faktor, baik faktor dalam dan faktor luar. Diantara faktor itu adalah motivasi yang cukup dominan dan dapat menggerakkan faktorfaktor lain kearah efektivitas kerja pelaksanaan pencapaian tujuan pendidikan yang berkualitas.

\section{Dari overregulasi menuju deregulasi}

Overregulasi pendidikan oleh pemerintah pusat telah membuat sekolah menjadi robot dan kehilangan eksistensinya. Paradigma pendidikan yang baru berupaya melakukan deregulasi pendidikan. Dalam paradigma baru, pusat hanya memberikan rambu-rambu yang menjadi standar nasional, selebihnya diserahkan kepada daerah dan sekolah untuk menentukan hal-hal yang bersifat teknis dalam pengelolaan pendidikan.

Deregulasi pendidikan diyakini akan mampu menumbuhkan daya kretifitas dan prakarsa sekolah, memberikan kelenturan kepada sekolah dalam mengelola sekolahnya, dan membuat sekolah sebagai pusat perubahan. Menurut Ichlasul Amal dikutip M. Sirozi (2003), bahwa institusi pendidikan harus berwenang penuh untuk mengelola sendiri manajemen pendidikan.

8. Dari mengontrol menuju mempengaruhi

Manajemen sentralistik cenderung menekankan pada mengkomandoi dan mengontrol secara ketat sehingga pelaksana selalu diawasi dalam melaksanakan pekerjaan pendidikan, sedangkan pendekatan MBS lebih menekankan pada mempengaruhi. Karena itulah pendekatan MBS dijalankan meskipun belum tersistem. Fungsi kontrol biasanya diberlakukan secara kaku itu $a$ historis, karena hanya menekankan pada bagaimana output dapat dicapai, dengan melupakan input dan procces yang menjadi output ini ada. Paradigma mempengaruhi lebih cenderung menekankan pada bagaimana, berarti proses pendidikan yang menjadi titik perhatian dan titik peningkatan mutunya untuk mengangkat mutu pendidikan, artinya ke depan berorientasi kepada proses pencapaian output yang berkualitas, sebab output itu adalah akibat dari suatu proses sebelumnya dan dilakukan dengan suatu standar kualitas tertentu yang bermutu. Karakteristik input dapat direkrut berdasarkan aspirasi yang berkembang tanpa ada unsur rekayasa. Input itu kemudian diproses dalam formulasi sistem yang 
relevan oleh sebuah teamwork yang kompeten dan memahami karekteristik Inputnya.

Orang yang mampu mempengaruhi orang lain itu, merupakan orang tersebut memiliki jiwa kepemimpinan. Kepemimpinan menurut Sutisna (1993) sebagai mempengaruhi kegiatan seseorang atau kelompok dalam usaha ke arah pencapaian tujuan dalam situasi tertentu. Sedangkan menurut Soepardi (1988) yang dikutip oleh Nanang Fattah adalah bahwa kepemimpinan sebagai kemampuan untk menggerakkan, mempengaruhi orang lain untuk mau bekerja dalam rangka mencapai tujuan. Dengan demikian ke depan visi paradigma pendidikan memerlukan pemimpin-pemimpin yang mampu memberikan suatu contoh-contoh, bukan pemimpin yang hanya mampu mengontrol tetapi tanpa memberikan pengaruhnya.

9. Dari mengarahkan menuju mengfasilitasi

Manajemen berbasis pusat lebih menekankan pada pemberian pengarahan, yang sering diwujudkan dengan kata-kata anda harus ke sana. Anda harus mengerjakan itu, dengan maksud agar pekerjaan cepat selesai. Sedangkan MBS lebih menekankan pada pimpinan yang memfasilitasi bawahannya agar bekerja secara kreatif. Misalnya bagaimana menurut pendapat anda untuk mengerjakan ini, bukan kerjakan ini, sesuai dengan petunjuk ini sedikit banyaknya perubahan paradigma dari mengarahkan menuju memfasilitasi, tergantung dengan kepemimpinan. Artinya perubahan paradigma dari mengarahkan menuju menfasilitasi maka penetapan program ditetapkan berdasarkan dari botton up bukan top down.

10. Dari menghindari resiko menuju mengelola resiko

Jika pola lama manajemen tradisional lebih menekankan pada menghindari resiko, maka pada pola manajemen baru lebih menganjurkan mengelola resiko. Hal ini didasarkan oleh kenyataan bahwa orang-orang yang berani mengambil resiko cenderung lebih maju dari pada orang-orang yang suka menghindari resiko.

Resiko berarti berhadapan dengan masalah, Menurut James A. F. Stoner (1993), mengatakan bahwa latar belakang dan keahlian para manajer akan mempengaruhi apa yang mereka anggap sebagai resiko/masalah dan kesempatan. Menurut William Pounds ada empat situasi yang merupakan sumber masalah, yaitu (1) bila ada penyimpangan dari pengalaman yang lampau, (2) bila ada penyimpangan dari rencana yang telah ditetapkan, (3) bila ada orang-orang yang menyajikan masalah kepada manajer, (4) bila para pesaing lebih berprestasi (Stoner 1993). Dengan demikian, masalah/resiko harus dicarikan jalan pemecahannya dan dikelola sebab masalah bukan saja menimbulkan kerugian/resiko semata-mata, tetapi masalah itu dapat memberikan peluang untuk lebiih berkualitas.

11. Dari menggunakan uang semuanya ke menggunakan uang seefisien mungkin

Kalau dalam pola anggaran lama lebih ditekankan pada uang harus dihabiskan semua, dalam MBS lebih ditekankan pada menggunakan uang secukupnya. Hal ini akan meningkatkan efisiensi keuangan sekolah. Tentu saja, ini menuntut restrukurisasi anggaran pola lama. Penggunaan dana dalam paradigma MBS tidak harus habis pada setiap akhir periode anggaran, tetapi justru harus ada saving.

Menurut Sirozi yang mengutip pendapatnya Joner (1985) tugas manajemen keuangan ada tiga fase, (1) financial planning, yaitu merupakan kegiatan yang mengkoordinir semua sumber daya yang tersedia untuk mencapai sasaran yang diinginkan secara sistematis tanpa menyebabkan efek samping yang merugikan. (2) Implementation 
yaitu pelaksanaan anggaran berdasarkan rencana yang telah dibuat dan kemungkinan terjadi penyesuaian jika diperlukan. (3) Evaluating, yaitu merupakan proses evaluasi tercapai sasaran anggaran.

12. Dari individu yang cerdas menuju teamwork yang kompak dan cerdas

Kecerdasan individu menjadi potensi sekolah yang perlu terus diberdayakan. Pada masa lalu, kecerdasan individu dianggap sebagai potensi individu yang bersangkutan, dan ditonjolkan kediriannya. Dalam MBS individu-individu yang cerdas itu harus diajak untuk memperhatikan kinerja sekolah secara keseluruhannya. MBS berasumsi bahwa teamwork yang kompak dan cerdaslah yang akan mampu meningkatkan mutu pendidikan/sekolah. Standar penilaian kinerja adalah hasil secara keseluruhan dan aktivitas komponen-komponen yang ada dalam sekolah. Jadi tidak sekedar predikat kepala sekolah berprestasi, guru berprestasi, staf terbaik, dan sebagainya. Tetapi paradigma baru memakai standar nilai itu adalah sekolah yang berprestasi.

13. Dari informasi terpribadi menuju informasi terbagi

Informasi sering hanya dimiliki oleh sejumlah warga sekolah, khususnya kepala sekolah serta wakil-wakilnya, dan beberapa guru tertentu. Pada MBS informasi harus tersebar atau terbagi secara merata pada seluruh warga sekolah dan stakeholder. Informasi itu kemudian diterjemahkan bersama oleh warga sekolah dan diolah menjadi kebijakan yang efektif. Tentu saja, yang dimaksudkan di sini adalah bukan setiap ada informasi baru harus disampaikan pada seluruh warga sekolah dan stakeholder, tetapi informasi harus diberikan kepada yang menang berhak untuk menerimanya.
Inti dari tulisan Ari Syari'ati (1986) itu, diantaranya adalah ia mengupas surat Ar-Rum, d iantaranya ayat 8 , yang berupa informasi itu tidak saja bersifat kepentingan jangka pendek (kehidupan manusia didunia), tetapi juga kepentingan jangka panjang (kehidupan manusia setelah kehidupan didunia) sebab menjadi bagian dari tujuan hidup kehidupan manusia ini.

\section{Dari pendelegasian menuju pemberdayaan}

Manajemen pendidikan kita sampai saat ini masih diwarnai oleh praktek-praktek pendelegasian tugas dan fungsi serta tanggung jawab semata, tanpa diikuti penyerahan kewenangan, sehingga sekolah tidak berdaya. Maka terjadilah pemaksaan pola terhadap sistem yang tidak sesuai. Inilah yang dimuat pada majalah Gerbang majalah pendidikan mengutip apa yang dikatakan oleh Paulo Fraire sebagai pendidikan yang membelenggu. Pada paradigma MBS, sekolah harus diberdayakan melalui penyerahan tugas dan fungsi, tanggung jawab, hak dan kewajiban, disertai kewenangan untuk mengambil keputusan.

Pemberdayaan lawan dari tak berdaya, agar berdaya dengan memberikan peluang untuk berkreasi dan inovasi dalam hal apapun intinya untuk mutu pendidikan, bukan hanya menerima/pendelegasian saja, tetapi adanya peluang yang bebas untuk melakukan kreatifitas tanpa batas.

15. Dari organisasi hirarki menuju organisasi dasar

Pola organisasi hirarkis menunjukkan adanya tirani dalam pelaksanaan pendidikan. Organisasi sekolah di atur dengan berlapis-lapis manajemen yang rumit sehingga sekolah lambat beradaptasi, mengantisipasi perubahan-perubahan, dan kurang tanggap terhadap isu-isu kritis/strategis yang menyangkut kemajuan sekolah. Melalui paradigma MBS, organisasi sekolah harus dibuat lebih dasar, 
dimana seluruh mitra kerja (bukan atasan dan bawahan) agar lebih responsif dan antisipatif, tidak saja terhadap isu-isu strategis/kritis yang dihadapi oleh sekolah, tetapi juga terhadap perubahanperubahan secara umum.

Menurut M. Sirozi (2004), paradigma baru itu dari struktur organisasi yang berbentuk kerucut, tetapi yang menentukan hanya bagian kerucutnya, berubah yang menentukan adalah bagian dasar dari kerucut itu, maka bagian kerucut yang kecil tidak lagi menentukan, melainkan bagian kerucut yang besarlah yang menentukan, artinya dalam menentukan mutu itu bukanlah dominan struktur yang tertinggi saja, tetapi menentukan mutu ditentukan oleh struktur yang paling bawah, jadi fungsi kerucut terbalik jadinya. Paradigma ini bila digambarkan sebagai berikut.

AtasHirarki

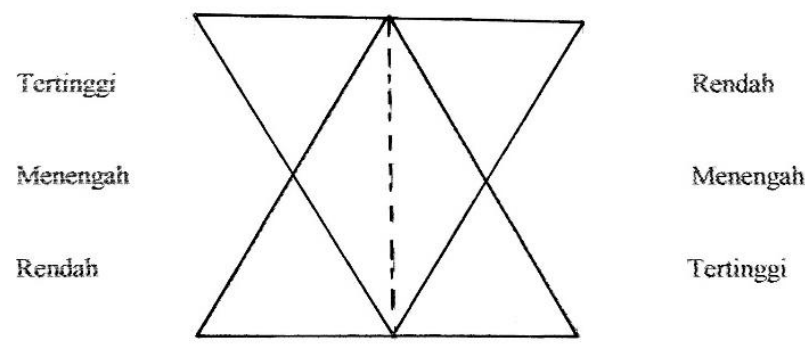

Atas Fungsidrasar

Gambar 1. Ilustrasi Struktur Organisasi Hirarkis Menuju Organisasi Fungsional Hirarkis

Paradigma baru berubah dari kekuasaan mengendalikan fungsi menuju fungsi mengendalikan kekuasaan.

\section{Kesimpulan}

Guru yang baik, ia selalu mengembangkan wawasannya dalam banyak hal yang berkaitan pada dunia yang ditekuninya, sebab hanya dengan seperti itulah ia dapat menjalankan tanggungjawabnya sebagi guru yang benar-benar guru, selain paradigma yang diatas itu perlu pula guru mengembangkan wawasannya dengan paradigma lain misalnya, seperti paradigma PBM dengan melakukan inovasi metodologi yang diterapkan, diantaranya paradigma PBM itu adalah berorientasi pada pengalaman siswa, PBM berawal dari kondisi awal siswanya lalu dikembangkan secara maksimal dengan merancang skenario PBM. Untuk menambah wawasan itu guru harus mau belajar menulis, sebab pendidikan itu adalah dunia ilmu, dimana semuanya dibuktikan melalui karyakarya ilmiah, riskan kalau sekolah sebagai dunia ilmiah tetapi budaya ilmiah tidak dikembangkan di sekolah.

\section{Daftar Pustaka}

Al-Qur'an dan Terjemahannya

M. Sirozi, 2004, Agenda Strategi Pendidikan Islam, cet.1. Ak. Group, Yogyakarta.

James A.F. Stoner 1993, Manajemen, Ed. 2. cet.4 Gelora Aksara Pratama, Jakarta.

E. Mulyasa, 2004, Manajemen Berbasis Sekolah : Konsep, Strategi dan Implementasi, Rosda, Jakarta.

Majalah Gerbang : Majalah Pendidikan. Ed. 1 tahun V-2005 UMY.

Nanang Fattah, 2004, Landasan Manajemen Pendidikan, cet.7. Remaja Rasdakarya, Bandung.

Muhammad Thohah Hasan, 2000, Diskursus Islam dan Pendidikan, Bina Wiraswasta Insan Indonesia, Jakarta.

Said Aqil Husin Al Munawar, 2003, Aktualisasi Nilai-Nilai Qur'ani : dalam Sistem Pendidikan Islam, cet.1, Ciputat Press, Jakarta.

Ari Syari'ati 1986, What Is To Be Done: The Enligtened Thinkers and Islamic Renaissance, Iris, Houston. Terjemahan Rahmani Astuti, 1998.

Mulyadi Kartanegara, 2005, Integrasi Ilmu : Sebuah Rekontruksi Holistik, Mizan-Uin, Jakarta Press, Jakarta.

Mulyadi Kartanegara, 2002, Menembus Batas Waktu : Panorama Filsafat Islam, Mirzan, Bandung. 
Mulyadi Kartanegara, 2004, Jalal Al-Din Rumi : Guru Sufi dan Penyair Agung, Teraju, Jakarta.

Mulyadi Kartanegara, 2003, Menyibak Tirai Kejahilan : Pengantar Epistimologi Islam, Mizan, Jakarta.

Nazarudin. M. (2007). Manajemen pembelajaran. Jogjakarta: TERAS.
RAHMAN, N. (2020). Manajemen Strategik.

Rahman. N. (2009). Manaiemen Pembelaiaran: Implementasi Konsep, Karakteristik dan Metodologi Pendidikan Agama Islam di Sekolah Umum. Cet I Yogyakarta: Pustaka Felicha. 